\title{
El valor añadido de la arquitectura vernácula: los casos de la Ruta del Vino y del Tequila en México
}

\author{
Aurora García García de León* \\ Universidad Autónoma de Baja California (México) \\ Elizabeth Rivera Borrayo** \\ Universidad de Guadalajara (México)
}

\begin{abstract}
Resumen: El turismo mexicano ha atestiguado un giro hacia la revalorización de las tradiciones como "atributos simbólicos" ubicados en zonas menos urbanizadas a través de una perspectiva sincrética que exalta tanto los valores prehispánicos como coloniales. En este contexto, las rutas temáticas se han convertido en una variante turística basada en el consumo de sitios diferenciados. En la Ruta del Tequila se manifiestan muchos de los efectos de la implementación del Programa Pueblos Mágicos, entre los cuales destaca la coexistencia de arquitectura patrimonial y neocolonial con elementos pertenecientes a otros períodos que intentan exaltar los valores estéticos de "lo mexicano". Mientras que la Ruta del Vino incorpora a su discurso arquitectónico valores asociados a la cultura fronteriza mediante el uso de materiales de segundo uso en una búsqueda por definir una arquitectura propia. Se parte de la hipótesis de que en ambas rutas temáticas la arquitectura funciona como un vehículo legitimador y que cada una expone un significado diferente de "lo vernáculo", a través de una diversidad de tipologías producidas que persiguen el mismo fin: atraer turismo. Así, se plantean diferencias y similitudes que nos llevan a reconocer la participación que está teniendo la arquitectura en la configuración de este tipo de destinos turísticos.
\end{abstract}

Palabras Clave: Turismo; Arquitectura vernácula; Rutas temáticas; Patrimonio; México.

The added value of vernacular architecture: the cases of the Wine and Tequila Route in Mexico

Abstract: Mexican tourism has been given a new twist by highlighting the significance of ancient traditions as "symbolic attributes" to be found in in lesser urbanised areas, a synchretic perspective not only focusing on colonial values but also on the pre-Hispanic civilisations. In this context, thematic routes have become a valuable tool toward taking tourists to various sites. The Tequila Route has been positively influenced by many of the effects of the implementation of the Magical Towns Programme, where various tangible and intangible heritage elements combine to convey "The flavour of Mexico". Meanwhile the Wine Route constitutes a fine example of "Border culture" vernacular architecture for tourists to enjoy. The authors underline the importance of architecture in shaping routes toward tourist destinations.

Keywords: Tourism; Vernacular architecture; Thematic routes; Heritage; México.

\section{Introducción}

Nuestra investigación se encuentra, en una primera instancia, bajo en el análisis de los procesos relacionados intrínsecamente entre sí, la arquitectura y el turismo, y que hoy forma parte de amplios debates sobre sus incidencias por las condiciones que hoy se manifiestan sobre el territorio. Lo que nos ha llevado a plantearnos diversas interrogantes relacionadas con los efectos y consecuencias que se producen en el territorio urbano sobre los procesos del turismo - a partir de programas como las Rutas Temáticas y Pueblos Mágicos -, que han dado un giro sobre las condiciones socio-culturales de una

\footnotetext{
* Professora da Universidad Autónoma de Baja California (México); E-mail: arq.aurora@gmail.com

* Universidad de Guadalajara (México); E-mail: elizabethrv@hotmail.com
} 
población determinada, y sobre todo, nos lleva a reflexionar sobre cómo estos pueden o no contribuir directamente en la recalificación en los entornos urbanos existentes.

Este trabajo se enfoca en el análisis de dos sitios diferenciados en los que se han aplicado dichos programas: la Ruta del Tequila (Jalisco) y la Ruta del Vino (Baja California Norte), con disímiles ambientes, tanto en su condición socio-cultural y valores arquitectónicos. Situación que nos ha llevado a plantearnos la premisa de que en ambas rutas temáticas la arquitectura funciona como un vehículo legitimador y que cada una expone un significado diferente de "lo vernáculo", a través de una diversidad de tipologías producidas que persiguen como fin la atracción de turismo.

En ese respecto, nuestro ámbito de estudio se relaciona con el análisis arquitectónico contextualizado socioculturalmente en espacios que representan elementos vivenciales en las comunidades o entidades en donde localizan dichos programas turísticos. Y por tanto, parte de nuestras técnicas metodológicas se encuentra en el análisis de las formas de observación cualitativa propia de la arquitectura y las ciencias sociales, a partir de distintas formas de registro, principalmente textual (descriptiva) y gráfico (por medio de imágenes y fotografías) derivado de visitas a ambos sitios, que permitan llevar a cabo un registro directo de información física de lugar. Como parte de las estrategias de la investigación social, una importante sección de nuestra investigación se basó en una amplia búsqueda documental de reconstrucción histórica urbana y cultural de los sitios de análisis seleccionados, con una revisión cuidadosa y sistemática de informes de investigación, literatura académica, entrevistas y demás documentos, con el fin de contextualizar nuestro análisis, elementos relevantes en la construcción del conocimiento desde la cultura material. A partir de las técnicas de recolección de información y el análisis observacional con el registro de lo que acontece en el sitio, nos permitió hacer una validación de la investigación.

Entendemos por otra parte que, como toda estrategia de investigación global, el caso de estudio ${ }^{1}$ formar parte importante dentro las ciencias sociales y de las humanidades, como una de las alternativas metodológicas para el análisis de una realidad concreta, principalmente a través de acciones de carácter activo e interpretativo, aplicable a múltiples áreas del conocimiento.

Respecto a los sitios de estudio se seleccionaron con base en la importancia que estas dos experiencias turísticas - la Ruta del Tequila y la Ruta del Vino- se encuentra hoy impulsándose en el campo de la promoción turístico-cultural donde se proyectan. Por tanto nuestro trabajo es de carácter interpretativo, donde la intensión no es generalizar los datos con otros hechos, es decir, no se trata de ejemplificar lo que sucede sino representar al suceso en sí, lo que nos permite entender y comprobar el fenómeno de hechos, evaluando el proceso de conformación e implicaciones sobre el territorio urbano. De la misma forma, el contraste de los sitios nos permite obtener dos fenómenos adversos ligados entre sí, la arquitectura y el turismo. Por otra parte, pretendemos que a partir de este trabajo de análisis, nos permita contar con herramientas metodológicas para establecer algunas directrices en el trabajo y un posible desarrollo en futuros análisis en el campo de interpretación hermenéutica dentro de otros contextos urbanos similares.

Por supuesto, como se ha expuesto, dicho análisis se encuentra apoyado con racionamientos teórico-conceptuales que permitieron describir y explicar la singularidad de situaciones específicas, y por ende, comprender una realidad concreta particular. Para ello fue necesaria una revisión de documentos académicos-científicos relacionados con las formas de producción arquitectónica y, sobre todo, los procesos de la turistificación de los espacios urbanos. Por este motivo, nuestras observaciones nos permitieron alcanzar una mayor compresión y claridad - tanto en lo teórico como metodológico - del hecho en sí, evaluando el proceso e implicaciones sobre un territorio urbano en particular, con la finalidad de desarrollar un debate más profundo de discusión de los postulados teóricos en el marco conceptual que le den sentido y alcance al fenómeno expuesto. Todo ello nos lleva a la realización de un acercamiento para la compresión socio-cultural de estos territorios, que nos permitan contar con una imagen o representación social y pueda describir una realidad poco explorada - desde este punto de vista particular- desde el rigor en el sentido que hoy exponemos dichos casos.

\section{Reflexiones teórico-conceptuales sobre el binomio arquitectura y turismo}

La arquitectura siempre ha tenido una relación intrínseca con el turismo. Desde sus inicios el turismo cultural, definido como "el primer tipo de turismo", alimentaba la búsqueda de la alteridad desde aquellas regiones en las que se hacía visible una diferenciación cultural. Y si bien dicha otredad 
se suele manifestar en prácticas culturales que resultan novedosas para el turista (MacCannell, 2003) su dimensión más tangible sería la edificada, como elemento configurador de su dimensión simbólica.

Uno de los primeros trabajos que reúne una colección de ensayos fue publicado en nuestro idioma hace más de una década. En Arquitectura y Turismo. Percepción, representación y lugar (Lasansky y McLaren, 2006) se establece un marco teórico que desborda el análisis exclusivamente arquitectónico y nos ofrece un abanico de interpretaciones que ponen de manifiesto que el estudio del turismo es mucho más complejo, pues se trata de un conjunto de prácticas que ejercen un impacto en las dinámicas urbanas y éstas requieren una lectura transversal.

Así el fenómeno turístico nos muestra, por un lado, que el patrimonio edificado ha sido revalorizado como objeto de consumo. La categoría de arquitectura patrimonial se es asignada cuando reúne las características de bien material al cual se le reconocen sus atributos físicos, históricos, técnicos, artísticos y emocionales; y este "valor asignado" es el vehículo principal que transmite una serie de experiencias estéticas diferenciadoras desde su dimensión simbólica, cual valor añadido, inserto en los circuitos turísticos como objeto de consumo.

Por otro lado, ante este fenómeno se presenta la arquitectura de más reciente cuño, que funciona como mediadora entre el turista y el producto a consumir; a la vez que opera como objeto mediático que pretende participar en la legitimación de una marca destino. La iconicidad de este tipo de arquitectura radica, además, en su capacidad plástica de poderse abstraer como forma reproducible (con efecto souvenir), optando por un "valor añadido" que, orientado hacia las lógicas del branding, debe echar mano de la llamada "arquitectura de autor", ese valor de marca que se asume poseen las firmas de las figuras de la arquitectura consagradas en el star system.

En el caso concreto del desarrollo vinícola y su incursión en los circuitos enoturísticos, es importante mencionar el análisis realizado por Llàtzer Moix (2010) en Arquitectura milagrosa, donde dedica su último capítulo a la arquitectura de autor en las bodegas vinícolas españolas como el artificio ideal para un nicho emergente en el mercado turístico. Se trata de inversiones exorbitantes con una arquitectura deconstructivista (o high tech) cuyo atractivo logró que las regiones rurales de La Rioja y El Duero, que tradicionalmente eran de paso, incursionaran en la hostelería ampliando así la experiencia turística y las posibilidades de consumo.

En este contexto, el turismo se diversifica a medida que la demanda se está expandiendo hacia nuevas experiencias. El caso del consumo turístico basado en sitios productivos no es tan novedoso como parece. Según MacCannell (2003), el turismo nace en un momento en que las horas de trabajo se reducen y aparece el tiempo libre. El trabajo es sustituido por el ocio y el surgimiento de la mercancía reduce la mirada del turista hacia los propios procesos de producción. La aparición de la clase burguesa trajo consigo una renovada y exótica visión del trabajo como proceso de transformación de las materias primas, es decir, el desarrollo de una mercancía vista desde su etapa germinal. Así mismo, con la aparición de un tipo de ocio "productivo", este es reforzado por "imágenes lúdicas que recuerdan que la 'jornada' turística es ante todo una experiencia de sensaciones: en ella se produce, se aprende, se descubre y hasta se descansa con el supuesto de la diversión, por lo que todo enganche al paquete es visual, pues así se inicia la construcción del viaje que sugiere ciertas vistas, sonidos, olores, colores, temperaturas, texturas y sabores" (Méndez, 2016, p. 11).

Así, el actual turismo basado en el consumo de lo que se produce en el lugar podría converger, por un lado, con el rescate del patrimonio industrial y la capitalización de arquitecturas vinculadas con otros tipos de turismo recientemente etiquetados como "agroturismo", "enoturismo", "turismo gastronómico", "ecoturismo", etc. Todos ellos dentro del ya consolidado turismo rural', enfocados en la experiencia "in situ" (Esteban, 2015) y de carácter más sensorial. Es así como en el marco de las rutas temáticas (es decir, itinerarios turísticos en torno a un tema) surgen aquellas basadas en el consumo de bebidas cuya producción va asociada con el lugar, su paisaje y su arquitectura. "El turista se desplaza al lugar de producción o elaboración, motivado por el disfrute de algún producto autóctono. Un claro ejemplo de ello son las rutas gastronómicas o enológicas, o las visitas a bodegas" (Bigné, 2011, p. 52).

Para ello Bigné (2011) identifica dos tipos de atributos al momento en que el turista visita una ruta temática basada en el consumo de un bien producido en el lugar, como puede ser una bebida: los atributos intrínsecos o internos, como la variedad y tipo de uva, el sabor, aroma, calidad técnica o la región de origen; y los atributos extrínsecos de productos con denominación de origen, como el precio, calidad percibida, marca, botella, asociación emocional y elementos diferenciadores. En este caso la arquitectura participa de ambos atributos (asociados con el lugar y los atributos diferenciadores que la misma provee) como el recinto mediador entre el turista (consumidor) y el producto de consumo (mercancía) (figura 1). Su papel como valor añadido provee al lugar de una imagen de marca reconocible 
y genera asociaciones de carácter tangible con el producto a consumir. En este contexto, al tratarse del consumo de un producto cultural "propio del lugar", la autenticidad recae también sobre los códigos arquitectónicos cual representación del lugar bajo las formas de lo vernáculo, en una búsqueda por instalarse en el imaginario del turista con una plástica diferenciada como valor añadido.

\section{Figura 1: Turismo y Arquitectura \\ Rutas Temáticas \\ Itinerarios turísticos en torno a una bebida}
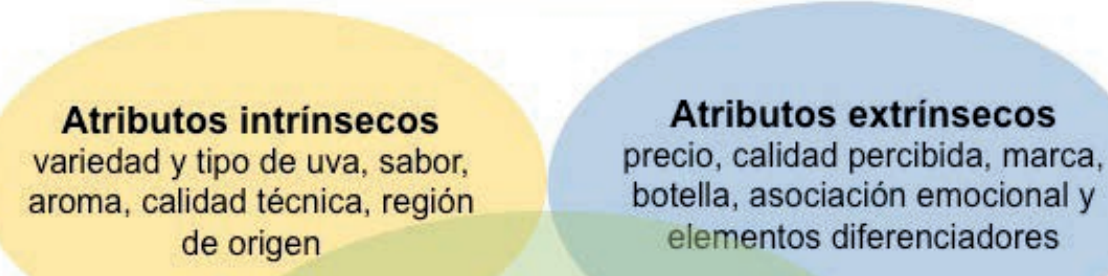

Arquitectura como mediadora

entre:

Turista (consumidor)

y

Producto de consumo (mercancía)

Fuente: elaboración propria retomado de Bigné (2011)

Para ello se ha optado por hablar de lo vernáculo como algo doméstico, dicho propiamente de la casa o el país (RAE) y por lo tanto, se sugiere, auténtico. "A las arquitecturas culta y vernacular se añadieron los calificativos de popular, tradicional, regional, rural, industrial, high tech, etcétera, y más recientemente, climática y sustentable (o sostenible)" (Tomas, 1998, p. 34). Es decir, lo vernáculo se entiende como la arquitectura "propia de cada región" que responde a necesidades específicas de un lugar y una época. Profundizamos así en los valores asociados a la autenticidad y por lo tanto, al patrimonio, y en este ejercicio de selección y síntesis recae la importancia de entender qué es lo que se designa patrimonio para comunicar lo "propio del país" que constituiría la tradición regional más auténtica y digna de conservar. En esa apuesta por la autenticidad es donde recaen muchos de los valores que el turista busca y sobre los cuales los propios desarrolladores del turismo arrojan luz.

En ese sentido, la búsqueda del turista lo llevará a encontrarse con un país cuya arquitectura ha evolucionado de tal manera que los dos momentos históricos más representativos (el prehispánico y el colonial) se han conjugado y tal sincretismo ha dado como resultado una tipología arquitectónica, que en el caso de las dos rutas a analizar (una al norte del país y otra al occidente) presentan algunas similitudes, pero también diferencias.

\section{Las rutas temáticas en México}

La segmentación del mercado turístico es una estrategia para llegar a un público más específico. Es por ello que la división tipológica de la actividad turística posibilita además un acercamiento a los lugares a partir de la profundización en un tema que se vuelve central. Tal es el caso de las rutas temáticas, las cuales buscan que el turista alcance una visión mucho más profunda y experiencial sobre un tema en específico que no necesariamente se ubica en un solo lugar, sino dentro de una ciudad, de una región o de un conjunto de regiones en puntos que pueden articularse a manera de itinerarios. En ese sentido, a pesar de que en Europa ya se habían consolidado algunas rutas temáticas, no es sino hasta el año 2005 que la UNESCO incluye los itinerarios culturales como una nueva categoría especifica en el nuevo 
texto de las Directrices de la Convención del Patrimonio Mundial. "Culminó así un proceso de reflexión científica sobre el concepto de Itinerario Cultural generado como consecuencia de la inclusión, en 1993, del Camino de Santiago en la lista de Patrimonio Mundial, y de la incesante labor del Comité Científico de Itinerarios Culturales (CIIC) de ICOMOS que postuló la necesidad de desarrollar una aproximación conceptual independiente y una metodología propia" (Tresserras, 2006, p. 14). Esta nueva categoría de patrimonio mundial desencadenó el esfuerzo de regiones con capital turístico por proyectar destinos agrupados a partir de ciertos temas específicos.

Un primer intento en la implementación de esta forma de turismo se da en México en mayo de 2010, cuando la Secretaría de Turismo lanza el programa "Las 10 Rutas de México", con el fin de ofrecer a los turistas "la oportunidad de poder combinar su visita a los destinos de sol y playa con el amplio patrimonio histórico y cultural de México" (Presidencia de la República, 2010). De entre los multi-destinos considerados, vale la pena destacar la presencia de las dos rutas a analizar aquí: la Ruta del Vino en Ensenada, en Baja California Norte y la del Tequila en Jalisco.

La primera prestaría interés a "La cultura del vino y el acuario del mundo", como titularían esta ruta que contempla la península de Baja California desde el Valle de Guadalupe hasta el avistamiento de ballenas, pasando por las misiones jesuitas y deportes extremos en el desierto. La segunda, bajo el título "El arte del tequila y la música bajo el sol", aparece como otra de las rutas ofertadas que contempla un territorio mucho más restringido a los campos de Agave Azul, el consumo del tequila y la música del Mariachi terminando en las playas de Puerto Vallarta. Sin embargo este intento resultaría un tanto forzado por tratar de agrupar o abarcar múltiples actividades en una región, en ocasiones inabarcables.

A pesar de ello, hay otras rutas en el mercado turístico mexicano que poco a poco se han ido posicionando. Tal es el caso de las rutas temáticas orientadas al consumo de bebidas; un segmento que ha logrado potencializar particularmente las zonas rurales por medio del impulso a la producción agrícola de donde se obtienen la mayoría de sus materias primas, así como a la hostelería y a la edificación de arquitecturas que propicien la fabricación, conservación, degustación y venta de sus productos. Es así como han emergido diferentes rutas en torno a bebidas producidas en el país, tales como la cerveza artesanal, el pulque, el mezcal (que adquiere diversos nombres según la región), el xtabentún, la charanda, el vino y el tequila. Siendo estos dos últimos los de mayor alcance comercial debido a la consolidación de su cultivo, su producción masiva, exportación y consumo (imagen 1 y 2 ).

\section{Imagen 1 y 2: Itinerarios para el recorrido de la Ruta del Tequila (izq.) y la Ruta del Vino (arriba).}
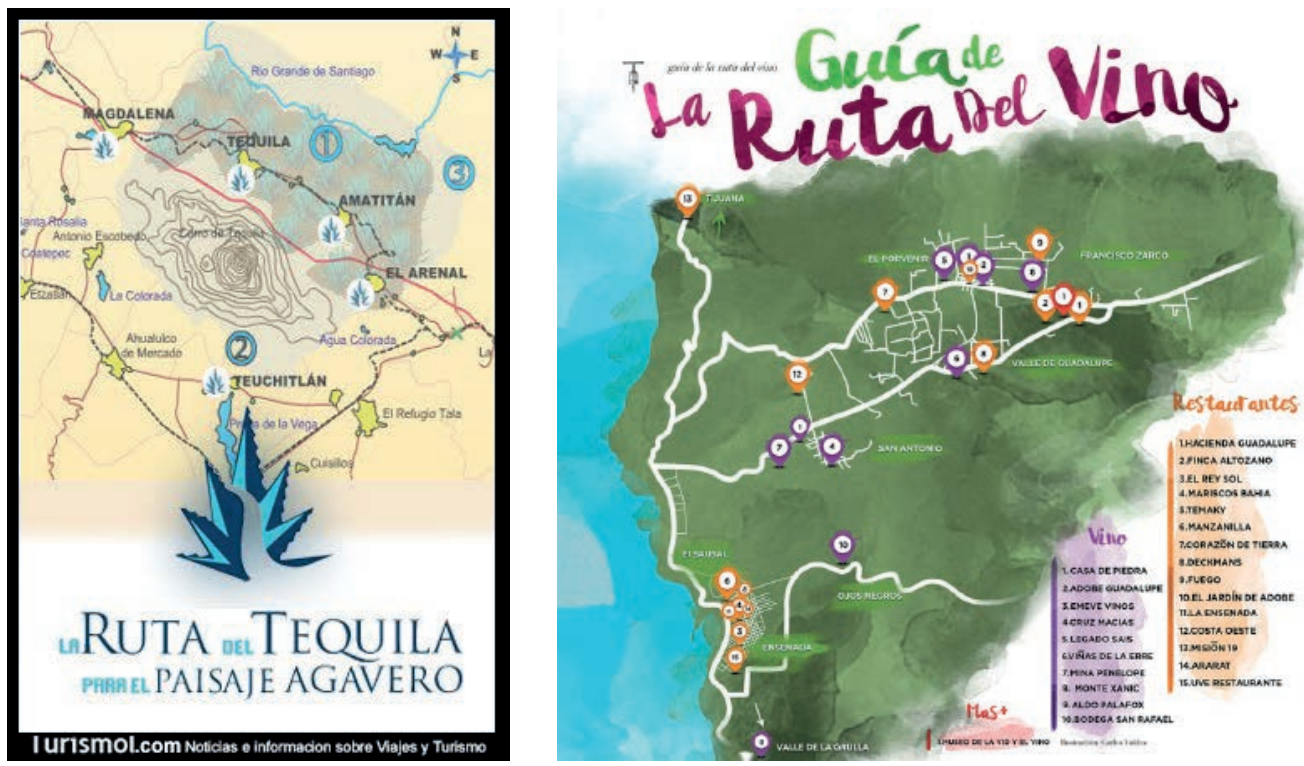

Fuente: turismo.com y Revista Todos Santos, respectivamente 
En este sentido, tanto la Ruta del Vino como la del tequila parten del mismo principio: atestiguar la producción de un bien de consumo en un recinto arquitectónico de carácter fabril, bajo el presupuesto teórico de que una vez que el ocio ha sustituido al trabajo éste se convierte en fenómeno observable y que, paradójicamente, el turismo cultural resulta mucho más "productivo" bajo una perspectiva didáctica.

En ambas rutas destacan discursos arquitectónicos que de alguna manera reposan sobre la idea de lo auténtico, de lo vernáculo. Por un lado, la Ruta del Tequila se ha logrado consagrar desde Jalisco cobijada por la metonimia de lo que es México, mientras que la Ruta del Vino poco a poco ha ido tomando fuerza en los circuitos turísticos y ha resignificado la arquitectura vernácula del norte. De tal manera que tanto las casas tequileras como las casas vinícolas articulan el itinerario de cada ruta temática como la parte más tangible y visible de cada producto, cual imagen de marca, como un dispositivo incuestionable de la autenticidad arquitectónica como valor añadido.

\section{La Ruta del Tequila}

Tequila, en Jalisco, fue de los primeros en suscribirse al programa Pueblos Mágicos en el año 2003. Esto representa el acceso a recursos federales que promueven el turismo facilitando la mejora de su infraestructura e imagen urbana, exaltando los valores diferenciadores y "mágicos" del pueblo para promover la atracción del turismo y así, en teoría, mejorar la calidad de vida de las comunidades locales por medio de su incorporación a esta actividad económica. La intención de rescatar dichas tradiciones, según la Secretaría de Turismo de México, tiene como objetivo "revalorar a un conjunto de poblaciones del país que siempre han estado en el imaginario colectivo de la nación en su conjunto y que representan alternativas frescas y diferentes para los visitantes nacionales y extranjeros" (SECTUR, 2014). En el caso del pueblo de Tequila, las asociaciones culturales sobre lo que es México giran primordialmente en torno a la producción de esta bebida con denominación de origen, determinado por el medio geográfico que le provee de un valor diferenciado que le da el derecho al uso exclusivo del nombre. Por esta razón las edificaciones destinadas a su producción cobran protagonismo, mientras que en términos arquitectónicos más generales los códigos responden a la arquitectura vernácula mexicana utilizada en la mayoría de este tipo de pueblos. Y aunque en su publicidad la Ruta del Tequila se define como un destino multitemático, a su vez se asume como "representativo de la mexicanidad" al conjugar "una riqueza histórica, patrimonial cultural y natural llena de tradiciones ligadas al desarrollo histórico de la bebida emblemática, la cultura del tequila y el México independiente" (La Ruta del Tequila, 2017).

Justo el mismo año en que Tequila es declarado Pueblo Mágico, se entrega a la UNESCO el dossier que propondría al Paisaje Agavero como Patrimonio Mundial. La propuesta incluiría los campos de agave, los vestigios arqueológicos, los pueblos de Amatitán, Arenal, Magdalena, San Juanito, Etzatlán, Ahualulco, Teuchitlán y Tequila (todos en Jalisco), así como la arquitectura, que contempla las antiguas instalaciones (destilerías y fabricas tanto activas como en abandono) para la producción del tequila (más de 30 en toda la región) y las edificaciones de valor patrimonial que se localizan en las áreas urbanas. Finalmente, en el año 2006 es aprobado como "sitio" y "paisaje cultural" (ICOMOS, 2006) y se adhiere englobado en el título de "Paisaje Agavero y las antiguas instalaciones de Tequila" que lleva dicho nombramiento y que podría prestarse a confusión, pues las haciendas y fábricas se encuentran no solo en el pueblo de Tequila sino en el conjunto de pueblos que articulan la ruta que lleva su nombre. "Tequila representa a la vez una bebida, una ciudad y un paisaje y esta mezcla rica en valores constituye una ventaja evidente para el turismo. Del producto (valor tangible) al paisaje agavero (valor intangible), cada uno de los elementos de valorización de Tequila funcionan de manera exitosa en su respectivo universo" (Ochoa et al, 2004, p. 41).

En este sentido es importante señalar el protagonismo que cobra la arquitectura destinada a la producción del tequila. Es por ello que para el estudio de las edificaciones que configuran esta ruta temática es necesario profundizar en los orígenes de la fabricación del tequila, las tipologías arquitectónicas que propician su producción y las nuevas dinámicas del turismo que participan en su intervención.

La producción del mexcalli tiene un origen prehispánico, similar al que se preserva hasta la actualidad para la producción del mezcal artesanal (cocinando las piñas en pozos), pero sin llegar al proceso de fermentación. Para el siglo XVI la producción del "vino de mezcal" se vio favorecida gracias a que en la Nueva España se adaptaron las técnicas y procesos europeos por medio de alambiques para la fermentación y destilación del mismo. 
"Hacia 1600 se introduce en la región el proceso europeo de destilación, de origen árabe, para producir el vino de mezcal, nombre que posteriormente toma el del lugar de origen: Tequila. Se basa en las experiencias para la producción de ron a partir de caña de azúcar traídas de las Antillas. (...) La actual utilización de diferentes tipos de coa en el proceso de cultivo de la planta tiene como raíz la herramienta de origen prehispánico. La siembra del agave en líneas paralelas, la utilización de hijuelos como medio de reproducción, el barbeo o despunte y la jima son algunos elementos que pertenecen a la tradición ancestral y que siguen vigentes en la región de Tequila después de milenios" (Gómez, 2006, p. 107-108).

Para la producción de este vino de mezcal, en la zona que abarca el Paisaje Agavero se desarrolló la edificación de tabernas, nombre con el que son conocidas regionalmente las antiguas destilerías de tequila. La proliferación de esta tipología arquitectónica, identificada por su emplazamiento subterráneo o semienterrado, se explica a partir de la incesante prohibición de la destilación del vino de mezcal (y todo tipo de bebidas alcohólicas) por parte de la Corona Española. Esto, con la intención de favorecer la importación de "caldos, vinos y aguardientes españoles". La proscripción de esta bebida regional durante los tres siglos del periodo colonial, propició la actividad clandestina de los tequileros hasta el siglo XVIII y fortaleció su identidad vinculándolos con el vino de su tierra.

"Esta actitud proteccionista durante el virreinato propició que las primitivas destilerías se alojaran en sitios apartados como las innumerables cañadas y barrancas que definen la difícil topografía de la comarca. En ese mismo periodo se comienzan a instaurar las tabernas como parte de las instalaciones productivas de las haciendas del territorio. Las haciendas tequileras se fueron consolidando alrededor de las faldas del volcán de Tequila, teniendo su periodo de auge en el siglo XIX. Desde mediados de ese siglo se comienzan a establecer en las márgenes del río que atraviesa la villa de Tequila adquiriendo a partir de ese momento un carácter plenamente industrial" (Secretaría de Cultura de Jalisco, 2003, p. 46).

Es por ello que la particularidad de la arquitectura inserta en esta ruta temática reposa sobre las instalaciones tequileras ${ }^{3}$ : destilerías, tabernas, haciendas y bodegas. Sobre estos cuatro géneros habría que aclarar que las tabernas son un tipo de destilería de carácter clandestino, mientras que las destilerías en general son instalaciones que se construyen con cercanía y accesibilidad desde la hacienda, y no pertenecen necesariamente al período de la prohibición. Por otro lado, destacar que aunque las bodegas antiguamente estaban anexas a la destilería y tenían un uso meramente industrial de almacenamiento, actualmente debido a la tendencia por reposar el tequila y por mostrar esta etapa de la producción a los circuitos turísticos, las bodegas se han convertido en una instalación que cobra cada vez mayor relevancia.

En cuanto a los valores arquitectónicos que le merecen a las instalaciones tequileras el nombramiento de Patrimonio de la Humanidad, podríamos asegurar que los criterios apuntan más hacia la relevancia de la actividad (la producción del tequila) que se llevaba a cabo en éstas que hacia una corriente arquitectónica concreta. Pues veremos cómo "se fueron introduciendo las corrientes arquitectónicas propias de su momento histórico. En ellas se pueden encontrar elementos formales de origen europeo y americano. El Barroco, el Neoclásico, el Neogótico, el Neocolonial, el Art Decó, el Funcionalismo o el estilo Internacional son algunos de los componentes estilísticos aplicados a estos inmuebles de género industrial" (Secretaría de Cultura de Jalisco, 2003, p. 47).

La configuración arquitectónica de este territorio se fue produciendo de manera evolutiva, pues narra la introducción de estilos arquitectónicos diversos y su interpretación local a lo largo de los siglos. En el caso de las instalaciones tequileras se identifica una organización espacial invariable que responde a una tipología industrial establecida. Esto se puede entender a partir del propio proceso de fabricación de esta bebida que requiere de construcciones esencialmente utilitarias. De tal manera que las variaciones son más perceptibles en términos arquitectónicos a través de la superposición de materiales y la introducción de innovaciones tecnológicas que en conjunto narran una historia que visita diferentes períodos:

"Debido a las características especiales de la materia prima que se procesa y al particular procedimiento de beneficio para obtener la bebida constituyen en su conjunto un género arquitectónico claramente diferenciado de otras instalaciones productoras de licores alcohólicas (sic) en el mundo. En la comarca se encuentran esparcidos numerosos vestigios arquitectónicos de diferentes periodos que en conjunto ilustran las etapas históricas por las que han transitado las antiguas instalaciones industriales de Tequila desde el periodo colonial hasta nuestros días, permitiendo una lectura clara de su permanente proceso de evolución" (Centro del Patrimonio Mundial de la UNESCO, 2006, p. 49). 
En este sentido es importante destacar la relevancia arquitectónica que también poseen los pueblos que configuran el Paisaje Agavero. En ellos destaca la coexistencia de arquitecturas de diferentes períodos, de carácter religioso y viviendas que suelen ser catalogadas como vernáculas por la utilización de materiales tradicionales y por ser generalmente autoconstruidas.

En el caso de Tequila habría que puntualizar en cómo el fenómeno turístico se manifiesta de manera concentrada a la vez que desarticulada, pues además de ser el pueblo protagónico de esta ruta temática y recibir una partida presupuestaria como Pueblo Mágico consolidado, se trata del pueblo que más ha capitalizado la simbología de "lo mexicano". En este sentido, Tequila ha sufrido una serie de transformaciones que poco a poco han ido desdibujando las características originarias del pueblo para dar cabida a un turismo masivo y ávido del contacto con el "México profundo". Para ello, se señala particularmente el enmascaramiento del pueblo por medio de arquitectura neocolonial, y "nueva arquitectura historicista" que simula ciertos elementos pertenecientes a otros períodos en un intento por exaltar los valores estéticos asociados con "lo mexicano" (González, 2010).

Las intervenciones tanto urbanas como arquitectónicas en esta nueva faceta turística de un pueblo dedicado durante toda su existencia a la fabricación de vino de mezcal, priorizan el flujo del turismo, a la vez que revisten de una arquitectura concertada las fachadas de las vías principales y más visibles ante la mirada ajena. En el pueblo "se ha construido nuevas edificaciones que recuperan el valor contextual de la arquitectura del siglo XVII y XVII vinculada con la figura de la hacienda tequilera" (González, 2010, p. 273). Al mismo tiempo que, conforme proliferan nuevas Casas Tequileras en la región, se pueden encontrar edificaciones recientes que replican la tipología de la hacienda ${ }^{4}$. Incluso se ha llegado a edificar una reproducción de una taberna completamente subterránea, lo cual ha despertado el interés del turismo y ha posicionado a esa casa tequilera ${ }^{5}$ dentro de las más visitadas. En cambio la arquitectura patrimonial o auténtica de los siglos XVI al XIX destinada a la producción, almacenaje y consumo del tequila está prácticamente abandonada. Para los propietarios de estas haciendas resulta más sencillo y económico construir un edificio nuevo anexo (en la misma propiedad) que restaurar el que tienen (imágenes 3 y 4).

\section{Imagen 3: Restaurante subterráneo que imita una antigua taberna en la casa tequilera "La Cofradía" en Tequila, Jalisco.}

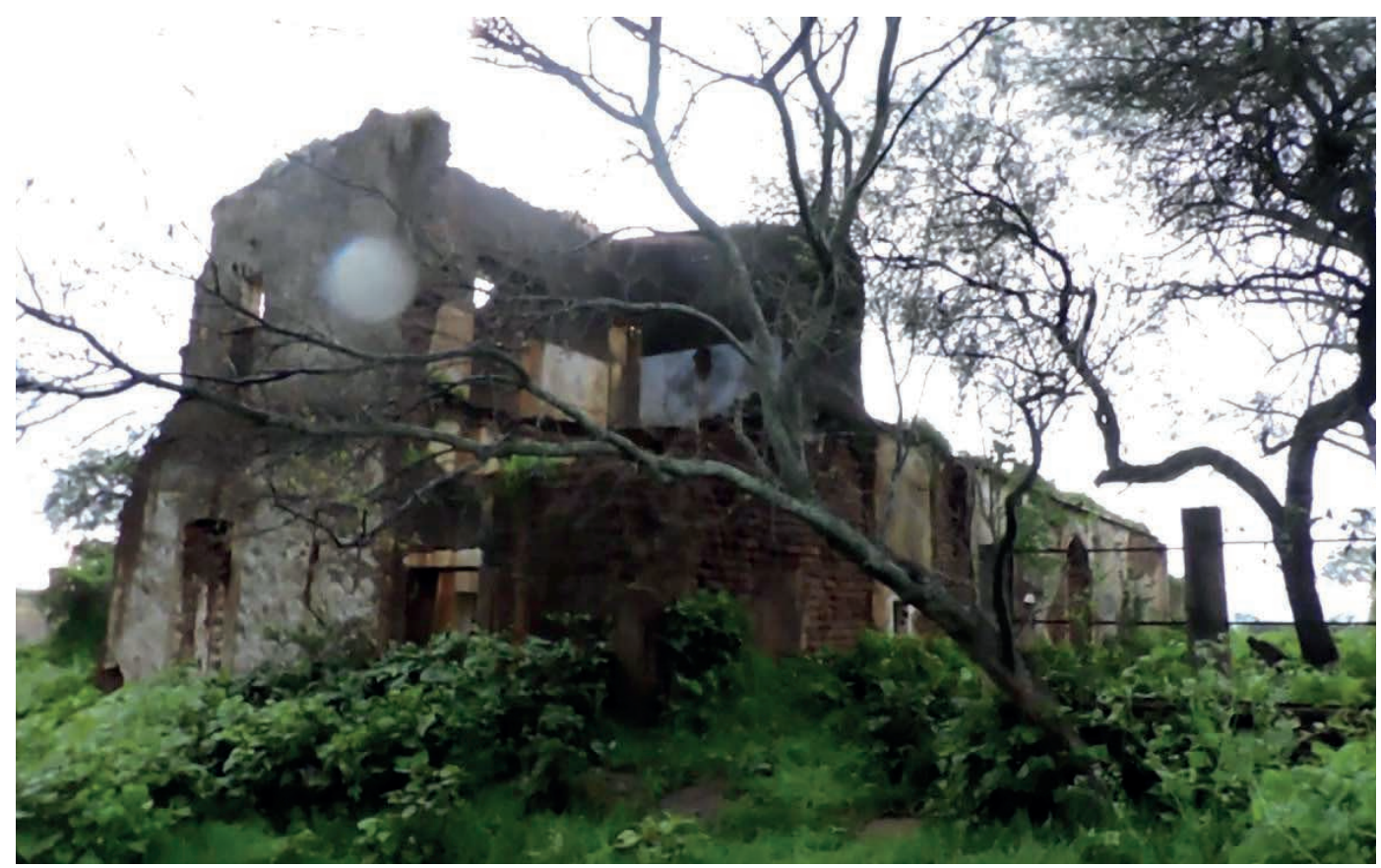

Fuente: Aportación del autor. 
Imagen 4: Ruinas de la antigua Hacienda La Cofradía en Amatitán, Jalisco.

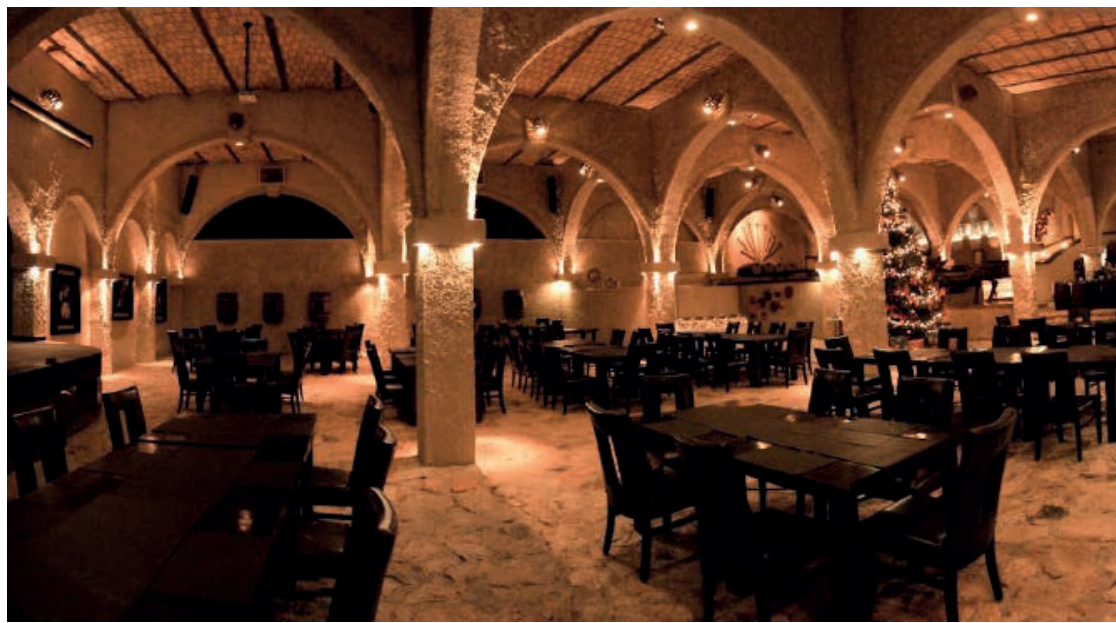

Fuente: extracto del video de Landeros, J. (2016).

APor ello, la Evaluación del Órgano Consultivo (ICOMOS, 2006) reconoce, por un lado, el buen estado de conservación en que se encuentran los sitios arqueológicos debido a su regulación (fundamentalmente a cargo del Instituto Nacional de Antropología e Historia), así como el de la arquitectura patrimonial dentro de los pueblos (todos ellos productivos y volcados primordialmente a esta actividad económica) y algunas de las destilerías y haciendas propiedad de las grandes compañías comerciales del tequila. Sin embargo, hace mención de las fábricas que no están en funciones, que aunque en su mayoría siguen en pie, algunas de ellas están en condiciones más vulnerables. Para su trabajo de conservación, la evaluación estipula apoyarse en el Plan de Manejo (Rodríguez y Hernández, 2006), sin embargo, a más de diez años de su estudio y catalogación ha sido casi imperceptible el avance, pues la mayoría de estos inmuebles siguen en total abandono. Esto significa que la arquitectura "vernácula" o propia de la región, con mayor tradición y que significó la configuración de estos pueblos como los máximos productores de esta bebida de mezcal, forma parte de la cara no visible para el turismo rural y para quienes incursionan en explorar por medio de esta ruta temática la autenticidad del lugar.

\section{La Ruta del Vino}

La zona vinícola alrededor de Ensenada concentra actualmente el 90\% de la producción nacional y el Valle de Guadalupe ha venido a consagrarse en los últimos años como el principal destino enoturístico del país, lo cual ha potencializado la producción de nuevos espacios que faciliten el contacto con la vitivinicultura y en los últimos años ha detonado la creación de construcciones singulares para pernoctaciones y el consumo gastronómico basado en el concepto de slow food ${ }^{6}$. Sin embargo las dinámicas turísticas actuales en esta región y el importante papel que ha jugado la arquitectura no se logran explicar sin la identificación de tres momentos clave a lo largo de su historia, que se remontan a la favorable localización de Ensenada, B.C. y su fundación como destino turístico.

Si bien la actividad vitivinícola se remonta a las misiones californianas que trajeron vástagos de vid para su cultivo durante el siglo XVIII, no es sino hasta 1888 que se funda Santo Tomás (localizada en la Antigua Ruta del Vino pero cuya bodega se localiza en el centro de Ensenada), que sería la primera en comercializar vinos en la región. Y aunque la marcada diferencia entre Aridoamérica y Mesoamérica logró ser relativamente homogenizada por el dominio español, en el caso de Ensenada sus orígenes como población integran otros ingredientes que lo convierten en un caso particularmente especial.

El establecimiento de las primeras casa vinícolas converge con la apertura de la ciudad hacia inversiones extranjeras que traería consigo la influencia de arquitectura anglosajona para finales del siglo XIX y principios del XX (Calderón y Geffroy, 2001), así como el desarrollo de dos motores económicos: la minería y posteriormente la pesca. Los orígenes de la actividad turística en Ensenada datan de un acontecimiento en particular, la Ley 
Seca en Estados Unidos a partir de 1919, que incentivaría la visita de norteamericanos hacia la franja norte de Baja California para el consumo legal de licor aunado a los juegos de azar y las apuestas; lo cual propiciaría el surgimiento de casinos y complejos turísticos para estos fines en Tijuana, Rosarito y posteriormente en Ensenada (Calderón y Geffroy, 2001). Este impulso turístico confluye hacia la década de los treinta con el desarrollo industrial, comercial y pesquero; mientras que el sector vinícola, apenas incipiente, tenía para entonces un lento crecimiento. En 1928 se instala L.A. Cetto y para 1948 la Casa Pedro Domecq en el Valle de Guadalupe, siendo junto con Santo Tomás los tres primeros productores vinícolas. Este período concluye con la revocación de la Ley Seca para 1933 y el posterior cierre del Hotel Playa y el Riviera en Ensenada. Posteriormente el crecimiento de esta ciudad, que en un principio fue de una admirable traza en su primer casco urbano, comienza a manifestar en el paisaje la escasez del suelo para los sectores más marginados. Esta situación originaría en las décadas del desarrollismo un crecimiento desordenado y la propagación de vivienda autoconstruida. Lo cual implicaría "la obtención de materiales de construcción de segundo uso y como consecuencia, el reciclaje de materiales de desecho de origen norteamericano" (Calderón y Geffroy, 2001, p. 88). Una situación que configuraría ciertos códigos en la autoconstrucción como un particular lenguaje que constituye muchas de las dinámicas culturales ensenadenses y de la cual se identifica una relación con la arquitectura que posteriormente veremos en la región vinícola de Ensenada.

Un segundo momento se identifica al inicio de la década de los noventa y tiene como escenario el estancamiento económico desencadenado por el embargo atunero (1991) y la paulatina desindustrialización de la ciudad ${ }^{7}$, que reemplaza dicha actividad por una de menor impacto y apuesta, en una encauzada lógica neoliberal, por el tercer sector; lo cual culminaría con la creación de la "Ventana al Mar" (el primer malecón de Ensenada) inaugurado en 1997 por Ernesto Zedillo y la apertura hacia la llegada de cruceros. Hasta ese momento el Valle de Guadalupe y Ensenada estaban desvinculados. La ciudad prácticamente no consumía vino a gran escala y la producción, bastante decaída, estaba completamente destinada a la exportación.

En ese contexto tiene inicio una paulatina regionalización y un cambio de velocidad en cuanto a la producción y la manera de concebir el consumo del vino. Con la llegada del enólogo Hugo D’Acosta, Santo Tomás cambia su producción de medio millón a tan solo 135 mil botellas al año, mientras que Monte Xanic incursiona en la particularización del Valle de Guadalupe como región vinícola y potencia la producción de vinos de boutique (de guarda), es decir, la producción comienza a orientarse hacia el vino de mayor calidad y en menor volumen.

\section{Imagen 5: Madera de barricas de vino recicladas y entramadas para formar un muro celosía.}

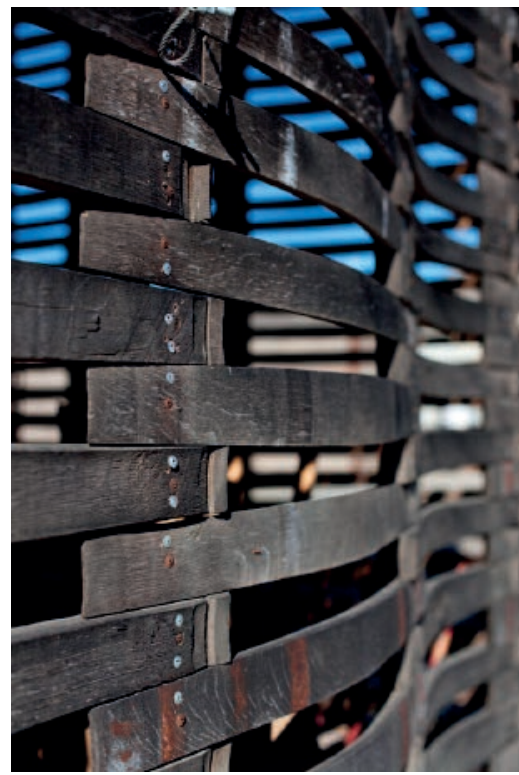

Fuente: Aportación del autor. 


\section{Imagen 6: Muro de block con revestimiento de botellas de vino ahogadas en concreto entintado.}

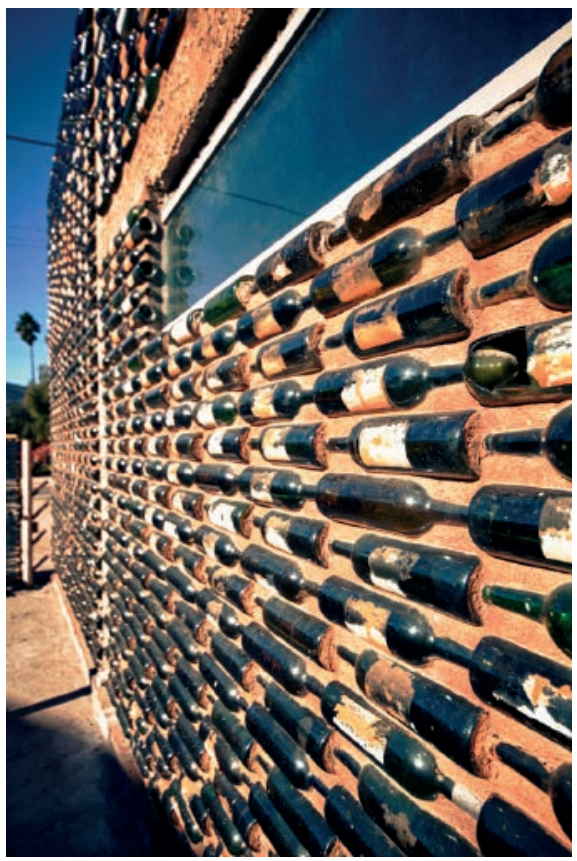

Fuente: Aportación del autor.

AEs así como en 1992 nace "La Escuelita" (Estación de Oficios El Porvenir), una vinícola pública que además de empezar a controlar los precios de la uva, surge como un centro dedicado a la restauración y el aprendizaje de los oficios por un colectivo de personas que comparten el gusto por la viticultura y que posteriormente se fueron convirtiendo en pequeños productores. Su importancia radica no sólo en el rescate de la cosecha de uva y la paulatina consolidación de la producción del vino de la zona, sino en a manera en la que se rescatan y reincorporan en la arquitectura materiales de desecho de la propia industria, como botellas de vino, piedra caliza, fragmentos de barricas y otras maderas y fibras sintéticas (imágenes 5 y 6 ).

En este experimento arquitectónico se pretende dignificar no sólo el oficio sino los materiales mismos, que en otro contexto (como en la autoconstrucción, por ejemplo) adquirían otras dimensiones simbólicas. En este sentido "La Escuelita" se puede considerar como un punto de inflexión, pues antes de su creación eran tan solo los tres latifundios de productoras antes mencionados los que comercializaban un producto de incipiente calidad que no participaba dentro del mercado de alta gama. La tierra pasa a productores locales, con lo cual se reconoce en la Estación de Oficios un esfuerzo por vincular el vino con la ciudad y fomentar la viticultura en comunión con su gastronomía a través de la promoción del maridaje en el lugar en el que los productos se fabrican y consumen. A este hecho habría que aunarle la llegada del chef Benito Molina a Santo Tomás y el movimiento cultural que ésta esta casa vinícola encabeza, lo cual repercutiría en la configuración del primer circuito culinario en el centro de la ciudad y las ya instituidas Fiestas de la Vendimia (1991).

El tercer momento se desencadena con el auge del turismo rural y muy particularmente con la consolidación de la industria vinícola en el Valle de Guadalupe. El paso al siglo XXI atestiguó el boom enoturístico y con ello la proliferación de decenas de casas productoras con una visión particular y una arquitectura diferenciada; aunado al desarrollo científico proveniente del cluster de investigación con el que cuenta Ensenada (Centro de Investigación Científica y de Educación Superior de Ensenada, Universidad Nacional Autónoma de México, Universidad Autónoma de Baja California) que propicia la innovación en la producción gastronómica y enológica. A partir del rescate de los viñedos esta zona comienza a proyectarse como destino consolidado teniendo como referencia el éxito del vecino Napa Valley pero con un lenguaje propio, trabajando con lo que hay en la zona. La particularidad de esta arquitectura es que en muchos 
de los casos se desprende de las prácticas más difundidas (arquitectura de autor, high tech, contenedores descontextualizados o envolturas), lo cual no significa que no hayan llegado a la región versiones adulteradas de casonas neocoloniales que destacan por su poca fidelidad con la historia y configuración del valle.

Ensenada, como algunas otras ciudades del norte del país tiene la particularidad de no poseer iconos arquitectónicos contundentes. Se trata de una ciudad joven (apenas fundada en 1882) que se ha ido proyectando lentamente. Aun con esto su paisaje urbano es reconocible y admirado, y la proyección que ha tenido como destino turístico se ha disparado gracias al "turismo de la experiencia", de la vivencia del paisaje del Valle de Guadalupe donde la arquitectura juega en ocasiones un papel "mediador entre el ser y el cosmos, que hace visibles las cualidades del entorno" (Pallasmaa, 2011, p. 156), que nos enmarca el paisaje e involucra al observador con lo que el propio contexto nos ofrece.

La Ruta del Vino ha adoptado la suficiente importancia en términos turísticos y arquitectónicos que merece la pena acercarse a donde se están generando tipologías arquitectónicas singulares, que retroalimentan el despunte de la ciudad de Ensenada como lugar ideal para vivir y visitar (desde el lenguaje del branding, la marca-lugar ideal); a la vez que proyecta los itinerarios enoturísticos de la región, en particular los del Valle de Guadalupe, participando así en la legitimación de una marca-destino.

La arquitectura que se puede encontrar en muchas de las casa vinícolas reflejan un vínculo entre el proceso de elaboración del vino y la reincorporación de los materiales de desecho del propio proceso, que por medio de la masificación de su uso se hacen visibles, aparentes. Unifican valores y reflejan un cúmulo de tradiciones asociadas con el lugar. La arquitectura que encontramos en la Ruta del Vino posee un lenguaje que proviene del antecedente local en la idiosincrasia ensenadense de reciclar materiales de desecho, por medio de la autoconstrucción debido a su fácil acceso. Este tipo de producción del espacio en el paisaje del valle pretende dignificar la "inmoralidad" de los materiales exponiéndolos y proveyéndoles de sentido. Se identifica así en su arquitectura cierto "sello" que se alimenta de lo vernáculo (entendido como lo hecho en la región y autoconstruido) y a su vez trasciende su entorno inmediato, pues permea en el paisaje urbano, descubriéndolo. Y en dicho sello radica ese valor añadido que lo está proyectando como marca-destino en el sector vinícola, pues su arquitectura deriva del propio proceso que respalda la industria, la proyecta y la sustenta (imágenes 7,8 y 9).

\section{Imagen 7: Vinícola Clos de Tres Cantos, construida con piedra extraida de la región, madera y botellas recicladas en puertas y ventanas.}

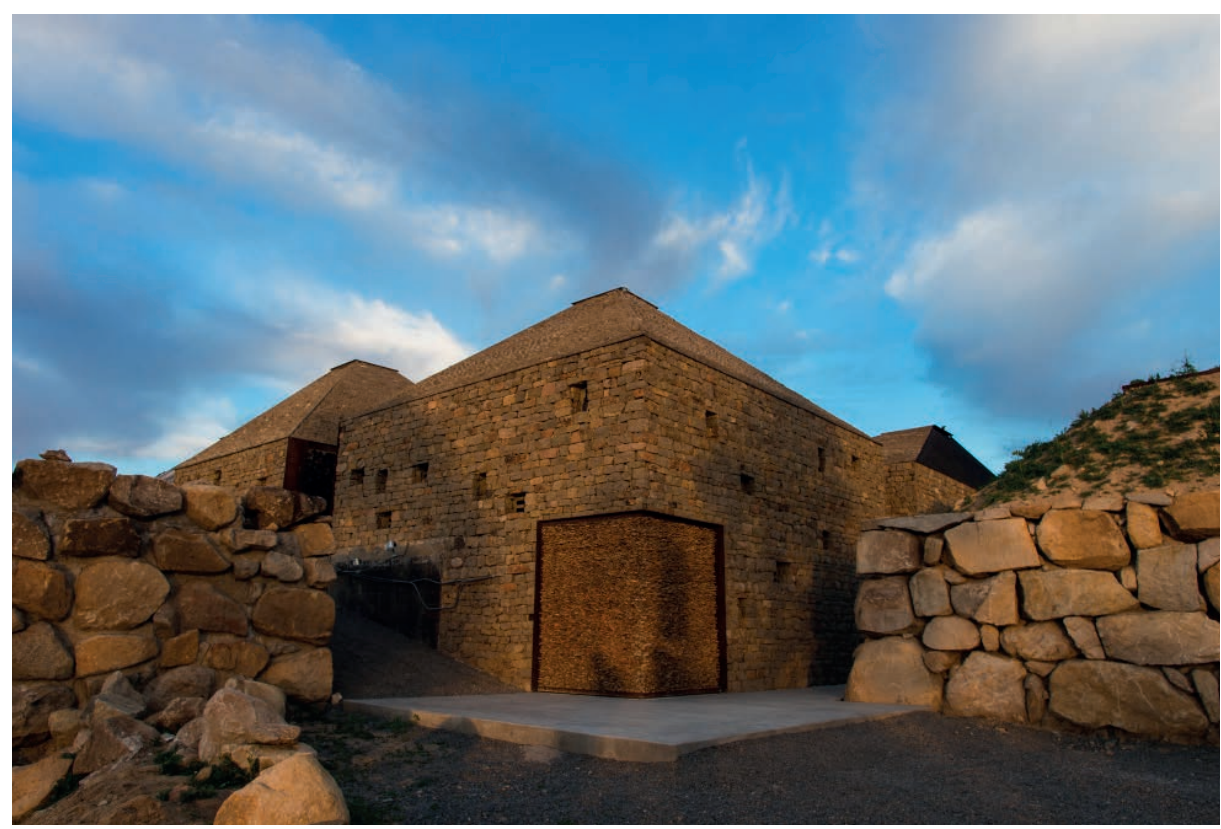

Fuente: Banco de imágenes de Taller de Arquitectura Contextual (7 y 8). Searching4zen.com (9). 
Imagen 8: Vinícola Vena Cava. Las cubiertas están compuestas por barcos reciclados que en su parte cóncava logran un interior confortable. Afuera, la cubierta de la terraza está hecha con mangueras de riego recicladas y trenzadas.

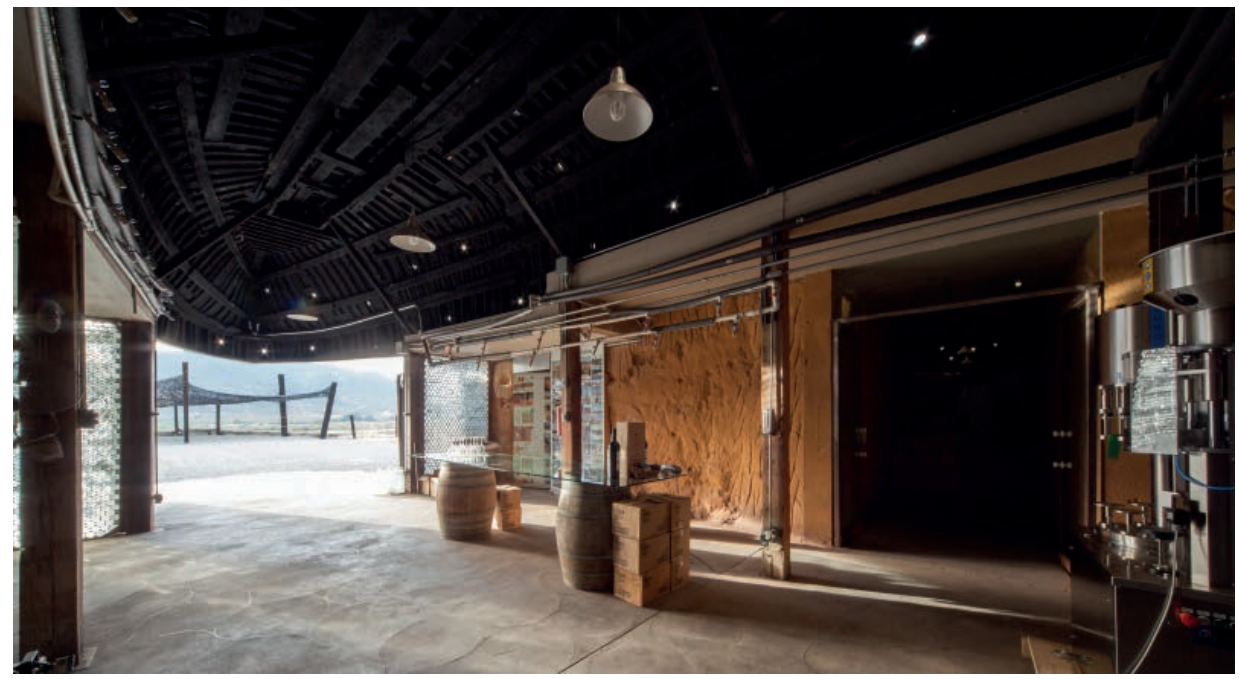

Fuente: Banco de imágenes de Taller de Arquitectura Contextual (7 y 8). Searching4zen.com (9).

Imagen 9: (derecha) Vinícola Sol y Barro, construida por el propio dueño con sistema COB (arcilla, tierra y paja) con la que contaba en su propiedad.

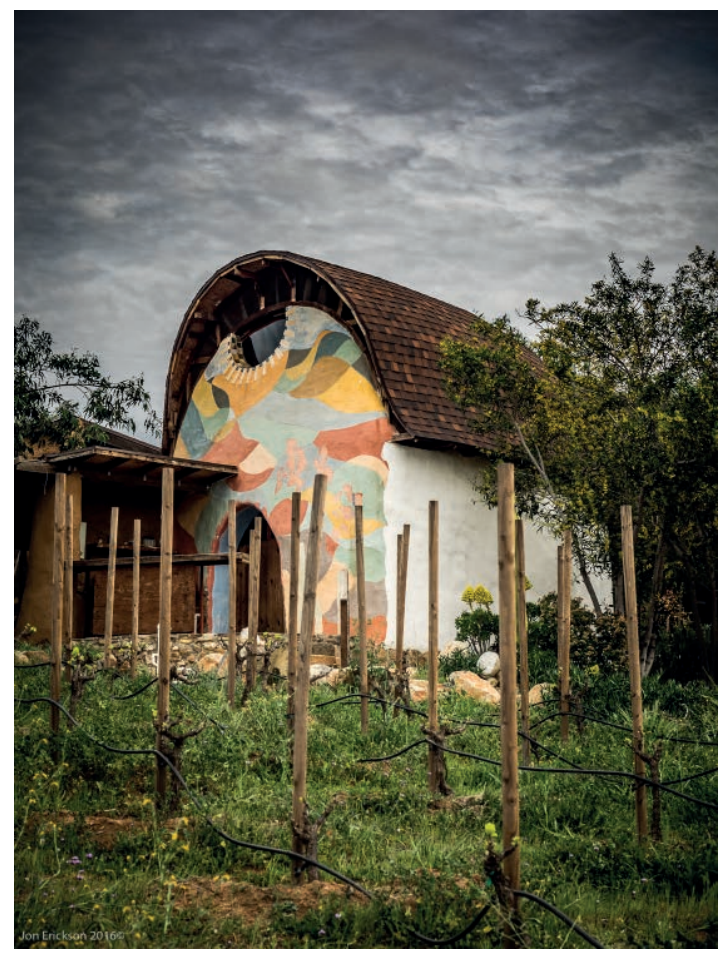

Fuente: Banco de imágenes de Taller de Arquitectura Contextual (7 y 8). Searching4zen.com (9). 
La producción del espacio en los destinos enoturísticos de Ensenada, en sus versiones más afortunadas gira en torno a la contextualidad. Ligar la arquitectura con el paisaje vinícola ha sido una práctica que en esta región se ha logrado posicionar como una característica diferenciadora de la marca lugar. A la vez que el discurso arquitectónico que sustenta su papel como elemento mediador ha venido a legitimar no solo un lenguaje sino una manera de hacer lugar, pues en la actualidad prácticamente toda la nueva arquitectura de alguna manera está reciclando y construyendo con lo que tiene en su entorno. "El paisaje puede interpretarse como un producto social, como el resultado de una transformación colectiva de la naturaleza y como la proyección cultural de una sociedad en un espacio determinado. Las sociedades humanas han transformado a lo largo de la historia los originales paisajes naturales en paisajes culturales" (Nogué, 2009, p. 11). La producción del espacio en este sentido juega un papel fundamental, pues en tanto que producto social llegan a ser incorporados en el imaginario como paisaje cultural para su consumo.

Es innegable el valioso papel que la Ruta del Vino está jugando para la consolidación de una marca lugar en Ensenada. En los últimos 25 años se ha pasado de tener 15 a más de 150 casas vinícolas, un número que va en aumento y que a su vez ha provocado una constante renovación de las vinícolas preexistentes y una evidente apuesta por la gastronomía y la oferta hotelera diferenciada (boutique, slow, rural, glamping, entre otros conceptos) que sugieren el bajo impacto ambiental y su respetuosa intervención en el paisaje. En cuanto a la arquitectura como legitimadora de una marca lugar en la Ruta del Vino en el Valle de Guadalupe, habría que hacer énfasis en la importancia del conocimiento profundo y previo de los procesos de producción del vino, pues han llegado a la región proyectos que fracasan porque sus arquitectos desconocen dichos procesos y por lo tanto la elaboración del vino se ve directamente perjudicada.

Así, en el caso de la Ruta del Vino, lo vernáculo reposa sobre lo que en esta zona del país es "propio de la región". Una forma de pensar que consiste en la reutilización de todo tipo de objetos y materiales que en algunos casos los norteamericanos desechan y que ahí se recuperan: desde objetos de gran escala como contenedores, casas rodantes, barcos, lanchas, coches y motos, hasta materiales como madera, acero, lámina, paneles e incluso objetos que no fueron creados para la construcción pero que aquí cobran un nuevo uso y significado. En este contexto, la autenticidad de la arquitectura de la Ruta del Vino reposa sobre esta manera de pensar y diseñar, y no necesariamente sobre los valores más ortodoxos asociados con lo patrimonial. Dentro de esta diversidad de tipologías (casi todas "vernáculas") paradójicamente las más falsas son aquellas que pretenden parecer antiguas misiones jesuitas o viejas casonas mexicanas. Una tipología refugiada en el falso histórico que también ha permeado en esta ruta temática pero que no ha logrado despertar el mismo impacto, a pesar de contar con una buena relación con el turismo masivo.

A esa tendencia por la tematización de los lugares del turismo habría que matizarle, en el caso de ambas rutas, el esfuerzo por la reutilización de los materiales, que ha llevado a algunos desarrolladores a reinterpretar esta práctica. Un ejemplo serían las habitaciones del Hotel Boutique Matices, que retoma la intención de interactuar con el paisaje agavero como lo hacen los búngalos de Encuentro Guadalupe con el paisaje vinícola. Sin embargo los resultados deja mucho que desear, pues sus habitaciones imitan una gran barrica de reposo del tequila, , que se desplanta levemente del terreno y en lugar de interactuar con el paisaje la disposición de cada una de ellas hace que el diálogo se lleve a cabo entre las propias barricas (imágenes 10 y 11). 
Imagen 10: Habitaciones de Matices Hotel de Barricas. Ubicado a unos cuantos metros de la casa tequilera "La Cofradía" en Tequila, Jalisco.

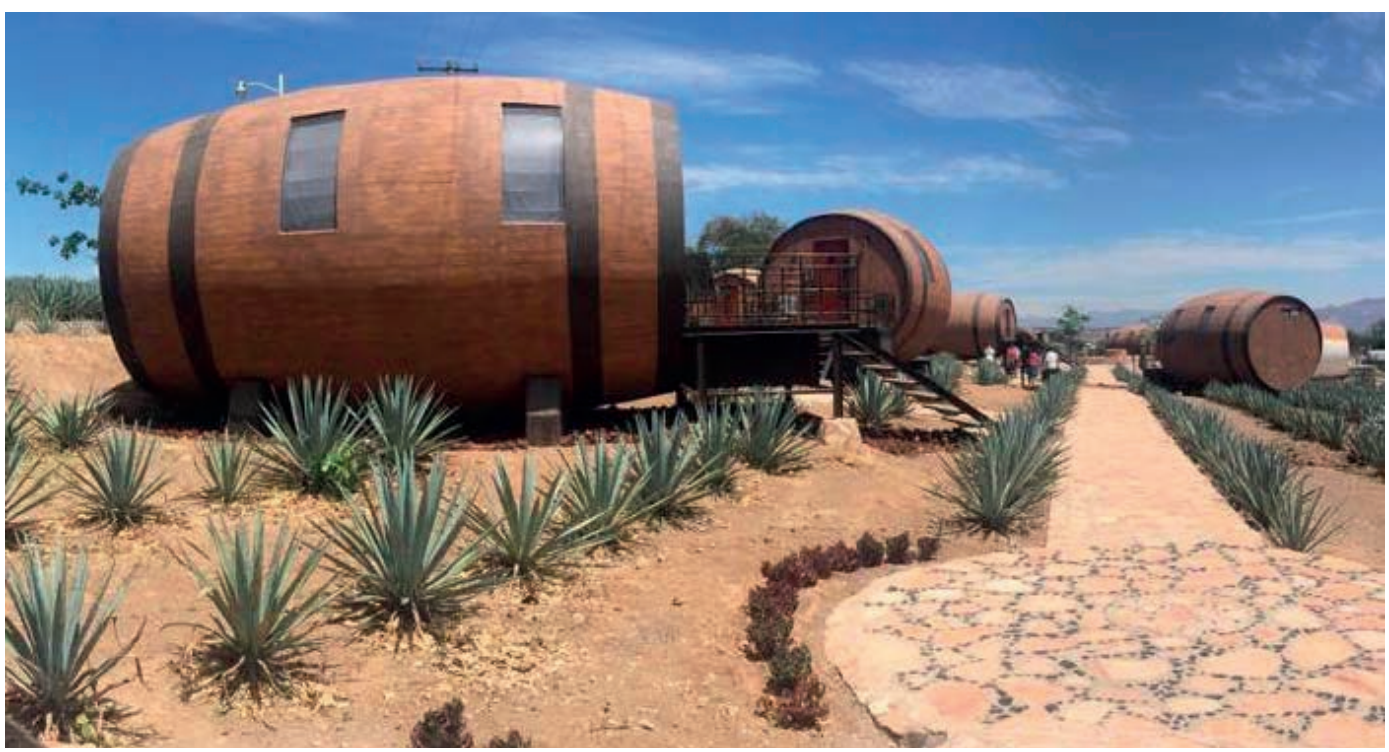

Fuente: Aportación del autor.

Imagen 11: Habitaciones del Hotel Endémico, en Encuentro Guadalupe dentro del Valle de Guadalupe en Baja California.

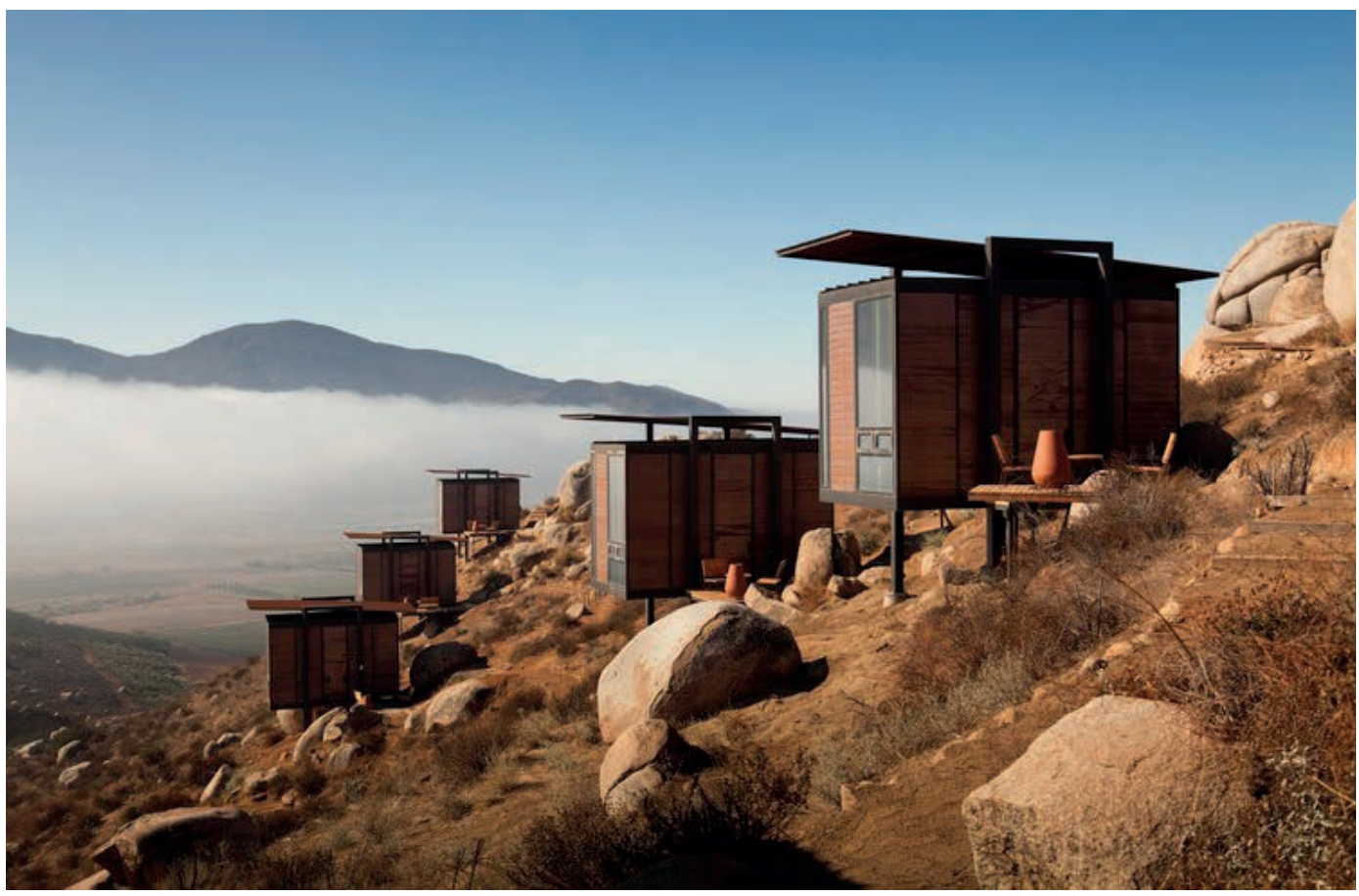

Fuente: Archdaily.com 


\section{Conclusiones}

Es innegable la participación que la arquitectura tiene en la legitimación de ambas rutas temáticas como destinos turísticos, pues estos están enfocados en el consumo de productos elaborados en el lugar, donde la arquitectura ha conseguido ser mediadora entre el turista (como consumidor) y el producto de consumo (la mercancía) como en el vino y el tequila. Para reflejar esa denominación de origen la arquitectura participa por medio de lo vernáculo, como "lo propio del lugar" ya que, si el vino y el tequila se fabrica con lo que la tierra les da, la arquitectura, en teoría, debe de ser coherente con ese discurso.

Dentro de las similitudes que podemos encontrar está que ambas rutas se basan en la producción de una bebida que en el caso del vino fue introducida por la corona española y en el caso del tequila ya se producía (como mezcalli) pero fue perfeccionada durante el virreinato. Lo cual en términos arquitectónicos se traduce en tipologías influenciadas por esta cultura: la de tipo colonial en el pueblo de Tequila y la de las misiones (jesuitas, principalmente) en el Valle de Guadalupe. Además, ambos itinerarios le dan una preponderancia a la contemplación de un paisaje agrícola geometrizado. Tanto el paisaje agavero como los viñedos responden a un diseño lineal y rítmico que se opone a la naturaleza salvaje y produce cierto placer estético.

Las tipologías arquitectónicas exitosas a los ojos del turismo de alguna manera se retroalimentan en estos dos casos, al igual que las estrategias: la Ruta del Tequila quiere replicar el modelo del Valle de Guadalupe en cuanto a la interacción entre las bodegas y el área de degustación con el paisaje agavero, mientras que en la Ruta del Vino ciertas casas vinícolas recurren a aparentar ser "más mexicanas" ante la mirada del turismo extranjero y por lo tanto incorpora a su lenguaje arquitectónico elementos propios de la zona de Jalisco.

En cuanto a las diferencias, tenemos que el paisaje agavero es cambiante, pues una vez se jima el agave después de 5 años de ser plantado, la tierra debe descansar y nutrirse antes de ser reforestada para lo cual se suele cultivar cacahuate o maíz en esos tiempos intermedios. Los viñedos, en cambio, son proyectos que tardan alrededor de 10 años en madurar y dar sus primeros vinos, sin embargo las vides tienen una larga vida, por lo cual el paisaje es variable debido a las diversas estaciones del año pero siempre en el mismo emplazamiento.

El agave se vuelve a plantar, la vid no. Esta condición hace que las haciendas tequileras no necesariamente tengan cercanía con lo que están cosechando, mientras que las casas vinícolas sí. Por ello la relación con el paisaje es distinta, pues mientras en la Ruta del Vino la arquitectura funciona como objeto mediador, en la del tequila el paisaje agavero queda en la mayoría de los casos excluido del circuito turístico enfocado en las casas tequileras (ubicadas en su mayoría dentro del pueblo que lleva el mismo nombre).

En cuanto a los recintos fabriles, tanto las zonas de producción como de almacenamiento y reposo del vino requieren de un cuidadoso control de la temperatura. El tequila no, pues se somete a un proceso de fermentación. Cada producto requiere cuidados diferentes y por esa razón las bodegas de vino tienden a ser subterráneas (para el control de la temperatura) y la arquitectura de Tequila que más se asemeja es la de las tabernas, que de origen son subterráneas por su clandestinidad, no por un especial cuidado hacia el producto.

Sobre el tema central de lo vernáculo; en el caso de la Ruta del Tequila, la autenticidad (lo original o propio del lugar), que radica principalmente en la arquitectura de carácter patrimonial, está escondida, abandonada. Mientras que en la Ruta del Vino la autenticidad radica en echar mano de lo que hay en el sitio para configurar sus propios códigos arquitectónicos.

En la Ruta del Tequila nos encontramos con un discurso arquitectónico que se repite a sí mismo hasta llegar a lo kitsch. En la Ruta del Vino descubrimos un laboratorio de arquitecturas diversas que experimentan con materiales, formas, métodos y que probablemente asuman esa libertad desde el desarraigo y la ausencia de una tradición arquitectónica potente como sucede en Jalisco. Podríamos decir que aunque nueva esta arquitectura es auténtica y por lo tanto es vernácula.

La conformación de estos tipos arquitectónicos analizados se retroalimentan de lo local y las tendencias globales para proyectar cada uno de estos lugares. En la ruta del Tequila lo autóctono (o "propio del lugar" no necesariamente de contrapone a lo foráneo (o lo "ajeno") sino que a lo preexistente se le han ido incorporando materiales, soluciones estructurales y elementos ornamentales propios de una época (la actual) en la medida en que las propias dinámicas del turismo así lo demandan. Mientras que las nuevas soluciones arquitectónicas del norte incorporan el reciclaje o la reutilización de materiales a su reclamo por legitimar esa conciencia local por medio de su lenguaje. Aquí lo todo lo "ajeno" se apropia y 
las arquitecturas catalogadas como foráneas recaen, curiosamente en la falsedad histórica de algunas vinícolas que replican el tipo de la hacienda vernácula del centro del país.

Por último, en el contexto del turismo es clave seguir arrojando luz sobre este tema controversial en torno a la autenticidad materializada en la arquitectura y lo vernáculo, pues así como se alude al sincretismo entre lo prehispánico y lo colonial, en un mundo donde cada vez menos cosas permanecen y las culturas se siguen fusionando y creando lugares cada vez más cambiantes, es difícil una taxonomía que identifique lo "original". El fenómeno turístico intenta retratar, congelar y sintetizar la identidad de un lugar y bajo ese principio el arraigo a imitar lo del pasado es una forma de crear ambientes "escenarios" no siempre acordes a su realidad espacio-temporal. Por ello, además de que se advierten arquitecturas cada vez más falseadas, se corre el peligro de generar una tendencia hacia las marcas reproducibles y lugares que redunden en lo mediático.

\section{Agradecimientos}

Programa para el Desarrollo Profesional Docente (PRODEP), Universidad Autónoma de Baja California, Universidad de Guadalajara

\section{Bibliografía}

Bigné, E.

2011. Las respuestas del turista ante la imagen del lugar de origen del producto. En Flavián, Carlos y Fandos, Carmina (Coords.) Turismo gastronómico. Estrategias de marketing y experiencias de éxito (pp. 51-68). Zaragoza, España: Prensas Universitarias de Zaragoza.

Calderón, C. y Geffroy, B.

2001. Un siglo de arquitectura en Ensenada. Baja California, México: Fondo Editorial de Baja California.

Centro del Patrimonio Mundial de la UNESCO (2006). El paisaje agavero y las antiguas instalaciones industriales de Tequila, México. Expediente técnico de postulación para la lista del patrimonio mundial de la UNESCO. Guadalajara, Jalisco: INAH, Gobierno del Estado de Jalisco.

Esteban, J.

2015. Turismo gastronómico y enológico. Madrid, España: Editorial Dykinson.

Galeano, M. E.

2007. Estrategias de investigación social cualitativa. El giro en la mirada. La Carreta Editores E.U., Colección Ariadna, Medellín.

Gómez, I.

2006. Patrimonio Mundial. El Paisaje Agavero y las antiguas instalaciones industriales de Tequila. En Patrimonio Cultural y Turismo. Cuaderno 15. Itinerarios Culturales (pp. 104-117). México: CONACULTA. Coordinación Nacional de Patrimonio Cultural y Turismo.

González, L.

2010. Modelo turístico sustentable para el municipio de Tequila, Jalisco, México: Una perspectiva del desarrollo local. (Tesis doctoral). Programa: Ciudad, Territorio y Sustentabilidad. Universidad de Guadalajara. Inédita.

ICOMOS

2006. Advisory Body Evaluation. The Agave Landscape (Mexico). No. 1209. Dimponible Disponible en línea en <file:///Users/aggl/Downloads/1209-ICOMOS-1386-en.pdf> (19/07/17).

Landeros, Jhonny

2016. Ruinas De La Cofradía Amatitan Jalisco. Video tomado de https://www.youtube.com/watch?v=Le_A_ GIyvo0.

Lasansky, M.y McLaren, B.

2006. Arquitectura y Turismo. Percepción, representación y lugar. María Jesús Rivas Centeno (Tr.) Barcelona, España: Editorial Gustavo Gili, S.L.

Maccannell, D.

2003. El turista. Una nueva teoría de la clase ociosa. (Primera edición 1979) Barcelona, España: Ed. Melusina S. L.

Méndez, E.

2016. El imaginario de la ciudad. Guadalajara. México: Universidad de Guadalajara. 
Moix, L.

2010. Arquitectura Milagrosa. Hazañas de los arquitectos estrella en la España del Guggenheim.

Barcelona, España: Anagrama.

Pallasmaa, J.

2014. La imagen corpórea. Imaginación e imaginario en la arquitectura. Barcelona, España: Gustavo Gili. Ochoa; Arias; López

2004. Turismo, ambiente y sociedad en Tequila, Jalisco. Una fórmula para la competitividad del territorio puesta a prueba. En Juárez, D.; Vera, A. (Coord.) Turismo sustentable y competitividad (pp. 41-70). Madrid, España: Cultiva Libros.

Presidencia de la República

2010. Mejorarán las 10 rutas de México la competitividad y la oferta turística. Comunicado 50/2010, Secretaría de Turismo. Recuperado de <http://calderon.presidencia.gob.mx/2010/05/mejoraran-las-10-rutas-de-mexico-la-competitividad-y-la-oferta-turistica/> (02/08/2017)

Rodríguez, J. y Hernández, H.

2006. Plan de Manejo. En Patrimonio Cultural y Turismo. Cuaderno 15. Itinerarios Culturales (pp. 120 -134). México: CONACULTA. Coordinación Nacional de Patrimonio Cultural y Turismo.

Ruta del Tequila

2017. Recuperado de http://www.rutadeltequila.org.mx

Sánchez, V. y Peribáñez, E.

2014. Turismo + Vino: Un binomio rentable. En Curiel, J. (Dir.) Turismo Gastronómico y Enológico (pp. 135-164). Madrid, España: Universidad Rey Juan Carlos, Dykinson, S.L., Fundación Ciencias Sociales y Mundo Mediterráneo.

Secretaría de Cultura de Jalisco

2003. El paisaje agavero y las antiguas instalaciones industriales de Tequila. Propuesta para su inscripción en la lista del Patrimonio Mundial de la UNESCO. Guadalajara, Jalisco: Cámara Nacional de la Industria Tequilera. Secretaría de Cultura.

Secretaría de Turismo

2014. Pueblos Mágicos. Recuperado de <http://www.sectur.gob.mx/gobmx/pueblos-magicos/> (10/08/17) Tomas, F.

1998. Después del funcionalismo, ¿qué? Hacia una nueva cultura urbana. En Sistemas urbanos. Actores sociales y ciudadanías (pp. 39-68). México: UAM-Atzcapozalco.

Tresserras, J.

2006. Rutas e itinerarios culturales en Iberoamérica. En Patrimonio Cultural y Turismo. Cuaderno 15. Itinerarios Culturales (pp. 14-56). México: CONACULTA. Coordinación Nacional de Patrimonio Cultural y Turismo. 